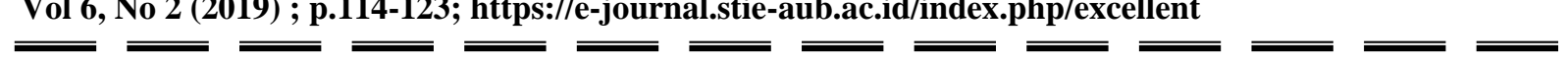

\title{
PENGARUH SISTEM INFORMASI AKUNTANSI TERHADAP KINERJA PEGAWAI
}

\author{
Putri Vera Rosdiana $\mathbf{H}^{1)}$ Dian Nur Mastuti ${ }^{2)}$ \\ STIE AUB Surakarta \\ Email: Putrivera1995@gmail.com
}

\begin{abstract}
ABSTRAK
Tujuan penelitian ini adalah Menguji dan menganalisis pengaruh Pemanfaatan Sistem Informasi Akuntansi, Kualitas Sistem Informasi Akuntansi, Keamanan Sistem Informasi Akuntansi dan Sarana Pendukung Sistem Informasi Akuntansi terhadap Kinerja pegawai PT.KMA Solo. Pengambilan sampel dilakukan dengan random sampling. Jumlah sampel dalam penelitian ini berjumlah 50 responden yang merupakan keseluruhan dari populasi penelitian yaitu pegawai PT.KMA Solo. Analisis data yang digunakan adalah uji asumsi klasik terdiri dari uji normalitas, uji multikolinearitas, uji heteroskedastisitas serta uji autokorelasi. Uji hipotesis yang digunakan adalah analisis regresi linier berganda, uji parsial (ujit), serta uji koefisien determinan. Berdasarkan hasil analisis data membuktikan bahwa; Pemanfaatan sistem informasi akuntansi berpengaruh positif dan signifikan terhadap kinerja pegawai PT.KMA Solo; Kualitas sistem informasi akuntansi berpengaruh positif dan signifikan terhadap kinerja pegawai PT. KMA Solo; Keamanan sistem informasi akuntansi berpengaruh positif dan signifikan terhadap kinerja pegawaiPT.KMA Solo; Sarana pendukung system informasi akuntansi berpengaruh positif dan signifikan terhadap kinerja pegawai PT. KMA Solo. Hasil uji $\mathrm{R}^{2}$ menunjukkan bahwa variable pemanfaatan sistem informasi akuntansi, kualitas system informasi akuntansi, keamanan sistem informasi akuntansi dan sarana pendukung sistem informasi akuntansi mampu menjelaskan terhadap variabel kinerja pegawai sedangkan sisanya dipengaruhi oleh variabel lain yang tidak diteliti oleh peneliti.
\end{abstract}

KataKunci: Pemanfaatan Sistem Informasi Akuntansi, Kualitas Sistem Informasi Akuntansi, Keamanan Sistem Informasi Akuntansi, Sarana Pendukung Sistem Informasi Akuntansi, Kinerja Pegawai

\section{ABSTRACT}

The purpose of this study is to examine and analyze the utilization of Accounting Information Systems, Quality of Accounting Information Systems, Accounting Information System Security and Supporting Facilities for Accounting Information Systems on the Performance of PT. KMA Solo employees. Sampling is done by random sampling. The number of samples in this study were 50 respondents which constitute the entire research study of PT. KMA Solo employees. Analysis of the data used is the classic assumption test consisting of normality test, multicollinearity test, heteroscedasticity test and autocorrelation test. The hypothesis test used is multiple linear regression analysis, partial test (test), and the coefficient of determinant test. Based on the results of data analysis proves that; The use of a positive and significant accounting information system on the performance of employees of PT. KMA Solo; The quality of the accounting information system is positive and significant to the performance of the employees of PT. KMA Solo; The security of accounting information systems is positive and significant for the performance of PT. KMA Solo employees; Means of supporting a positive and significant accounting information system on the performance of employees of PT. KMA Solo. R2 test results indicate that the variables use accounting information systems, the quality of accounting information systems, accounting information systems and accounting information system supporting facilities explain the variables

Keywords: Efficiency of Accounting Information Systems, Accounting Information Systems, Accounting Information Systems, Supporting Facilities of Accounting Information Systems, Employee Performance

\section{PENDAHULUAN}

Penggunaan teknologi informasi diera sekarang ini merupakan elemen penting dalam aktivitas perusahaan. Sistem informasi membawa pengaruh besar terhadap hampir semua aspek dalam pengelolaan bisnis, termasuk dalam pengelolaan perbankan. Perkembangan sebuah sistem informasi juga perlu didukung oleh banyak factor yang diharapkan bisa memberikan keberhasilan dari sistem tersebut. Keberhasilan aplikasi system informasi pada suatu perusahaan atau perbankan dipengaruhi dari cara sistem itu dijalankan, tingkat kemudahan sistem itu bagi para pemakainya,dan pemanfaatan teknologi 
yang digunakan. Menurut Bodnardan Hopwood (2003:23) "sistem informasi akuntansi adalah berbagai sumber daya seperti peralatan dan manusia yang diatur guna mengubah data hingga menjadi informasi". Sistem informasi akuntansi merupakan sub sistem dari SIM (Sistem Informasi Manajemen)yang menyediakan informasi keuangan, serta informasi lainnya yang diperoleh dalam proses rutin transaksi akuntansi (JonesdanRama,2006). Sistem informasi akuntansi adalah suatu bagian organisasi yang mengumpulkan, menggolongkan, mengolah, menganalisa dan komunikasikan informasi keuangan untuk pengambilan keputusan kepada pihak luar perusahaan (pemerintah, otoritas pajak, dan calon pemegang saham) dan pihak dalam perusahaan dalam halini para pemegang saham (Baridwan, 2004:4). Sistem informasi akuntansi ini dirancang oleh suatu perusahaan untuk memenuhi fungsinya guna menghasilkan informasi akuntansi yang relevan, tepat waktu, dan dapat dipercaya.

Salah satu fungsi penting sistem informasi akuntansi adalah pengendalian internal. Salah satu objek pengendalian internal adalah kinerja perusahaan dan kinerja pegawai didalamnya. Menurut Mangkunegara (2002)"kinerja diartikan sebagai kualitas dan kuantitas dari hasil kerja yang telah dicapaioleh pegawaidalam melaksanakan tugasnya sesuai dengan tanggungjawabnya".

Pengukuran kinerjadapat menggunakan pendekatan "input- proses-output" dengan menggunakan indicator prestasi kerja, kerja sama, dan tanggung jawab (Achmad,2001). Indikator lain dapat juga digunakan sebagai alat ukur kinerja pegawai, yaitu kualitas kerja, kuantitas kerja, ketepatan waktu, pengawasan supervisor, efektivitas biaya, dan pengaruhrekan kerja (Andhika, 2007). Kinerja perlu dinilaiuntuk mengetahui tentang pelaksanaan tugas, seperti kesulitan yang dihadapi dan bagaimana penyelesaiannya, serta apakah tujuan atau organisasi telah tercapai.

PT. KMA Solo merupakan salah satu perusahaan yang menerapkan sistem informasi akuntansi dalam kegiatan sehari-harinya. Diakui oleh pegawai PT. KMA Solobahwa dengan menggunakan system informasi akuntansi yang terstruktur dapat memberikan kemudahan dalam proses pekerjaan pegawai sehari-hari. Dengan adanya penerapan sistem informasi akuntansi perusahaan, maka segala aktivitas atau transaksi dapat diawasi dengan baik dan lebih tersusun.

\section{TINJAUANPUSTAKA}

\section{Sistem Informasi Akuntansi}

Romney dan Steinbart (2006:2-3) mendefinisikan "sistem adalah rangkaian dari dua atau lebih komponen-komponen yang saling berhubungan, yang berinteraksi untuk mencapai suatu tujuan". Sistem hampir selalu terdiri dari beberapa subsistem kecil, yang masing-masing melakukan fungsi khusus yang penting untuk dan mendukung bagi sIstem yang lebih besar, tempat mereka berada.

Sistem Informasi Akuntansi (SIA) terdiri dari lima komponen yaitu sebagai berikut (Marshall B. Romney,Paul john steinbart, 2006): Orang-orang yang mengoperasikan sistem tersebut dan melaksanakan berbagai fungsi.

Posedur-prosedur, baik manual maupun yang terotomatisasi, yang dilibatkan dalam mengumpulkan, memproses, dan menyimpan data tentang aktivitas-aktivitas organisasi. Data tentang proses-proses bisnis organisasi. Software yang dipakai untuk memproses data organisasi. Infrastruktur teknologi informasi, termasuk komputer, peralatan pendukung (peripheral device), dan peralatan untuk komunikasi jaringan.

Sistem Informasi Akuntansi memiliki semua karakteristik sistem informasi manajemen. Mereka memanfaatkan jenis sumber-sumber yang sama dan mempunyai siklus pengolahan data yang menghasilkan informasi untuk perencanaan dan pengendalian manajemen. Sistem informasi akuntansi hanya mencakup jenis dan informasi tertentu. Jadi sistem informasi akutansi adalah suatu sub sistem dari sistem informasi manajemen dalam suatu organisasi (Kosasih, 1995:16-17).

\section{Pemanfaatan Sistem Informasi Akuntansi}

Pemanfaatan Sistem Informasi akuntansi dapat dilakukan pada aktivitas perusahaan yang terbagi ke dalam beberapa subsistem dari Sistem Informasi Akntansi, yaitu (Hall, 2009): Sistem pemrosesan transaksi (Transaction Processing System-TPS) Sistem buku besar atau pelaporan keuangan (General ledger or Financial Reporting System GL/FRS) Sistem pelaporan manajemen (Management Reporting System-MRS) Pemanfaatan sistem informasi akuntansidapat diketahui dari keberadaan komputer, software, serta jaringan internet. Proses akuntansi dapat didukung oleh bantuan software akuntansi yang 


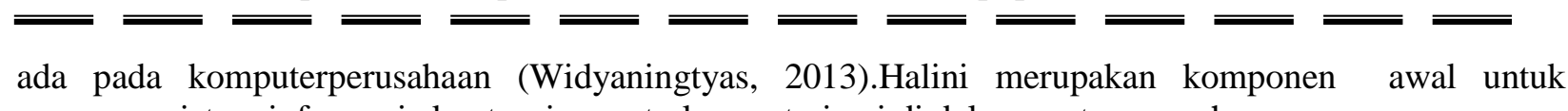
penerapansistem informasi akuntansi yang terkomputerisasi di dalam suatu perusahaan.

\section{Kualitas Sistem Informasi Akuntansi}

Kualitas sistem dan kualitas informasi yang dihasilkan akan menentukan bagaimana penggunaandan kepuasan penggunaatas penerapan sistem informasi akuntansi dalam perusahaan. Kemudian hal tersebut akan berdampakpada kinerja dari individu, dan selanjutnya akan mempengaruhi kinerja perusahaan.

Kualitas sistem informasi akuntansi merujuk pada kualitas software yang digunakan di perusahaan. Keberadaan software dipercaya dapat mempermudah proses akuntansi sebagai pelengkap penggunaan komputer. Beberapa kriteria software yang dapat digunakan pada perusahaan adalah mudah dimengerti serta dapat meningkatkan relevansi, akurasi, keringkasan, kelengkapan, dan ketepatan waktu bagi laporan perusahaan. Salah satu software yang umum digunakan adalah Microsoft Excel.

\section{Keamanan Sistem Informasi Akuntansi}

Teknologi terus berkembang dan menghasilkan berbagai penemuan yang bermanfaat yang memberikan kemudahan bagi seluruh aktivitas perusahaan. Namun berbagai kemajuan tersebut diiringi oleh berbagai ancaman yang dikhawatirkan akan merusak sistem informasi akuntansi. Keamanan atas sistem informasi akuntansi pun mulai menjadi perhatian dan focus utama pada saatini. Titisari (2015) mengatakan bahwa "teknologi yang baik dan dapat diandalkan adalah yang dianggap aman bagi penggunanya".

Kemananan sistem merupakan bagian dari kualitas sitem yang nantinya akan mempengaruhi kepuasan pengguna sistem informasi akuntansi. Keamanan sistem informasi akuntansi akan berdampak pada data yang terkandung dalam informasi yang dihasilkan. Dengan demikian, kualitas informasipun menjadi diragukan apabila tidak terdapat proteksi pada sistem informasi akuntasi. Menurut Robert dan Steinbart (2011),"Sistem informasi akuntansi dapat menghadapi beberapa ancaman".

Peningkatan ancaman-ancaman sistem informasi akuntansi pada saat ini juga dikarenakan oleh permasalahan pada sistem pengendalian yang ada di dalam perusahaan.

\section{Sarana Pendukung Sistem Informasi Akuntansi}

Sistem informasi akuntansi diharapkan dapat mendukung penyajian informasi keuangan ataupun non keuangan secara akurat dan tepat waktu. Untuk menyempurnakan manfaat yang diperoleh dari penerapan sistem informasi akuntansi, maka digunakan tambahan sarana pendukung. Sarana Pendukung Sistem Informasi Akuntansi dipercaya penting untuk dapat menambah efektivitas penerapan sistem informasi akuntansi. Dengan adanya Sarana Pendukung Sistem Informasi Akuntansi diharapkan Sistem Informasi Akuntansi dapat memberikan mafaat yang optimal bagi perusahaan.

Beberapa perusahaan tidak menggunakan komputer serta sistem yang terkomputerisasi. Hal tersebut dapat menjadikan komputer dan software berada pada kategori sarana pendukung dalam penerapan sistem informasi akuntansi. Jaringan internet seperti WAN dan LAN juga merupakan contoh lain dari sarana pendukung dalam penerapan sistem informasi akuntansi.

Keberadaan lingkungan kerja yang nyaman juga dapat berpengaruh terhadap efektivitas penerapan sistem informasi akuntansi. Salah satu contohnya adalah ketersediaan ruangan yang memadai bagisistem serta kenyamanan dan kerapihan ruangan yang dapat memberikan tambahan motivasi atau semangat bekerja para pegawai dalam meningkatkan kinerjanya (Titisari, 2015).

\section{Kinerja Pegawai}

Dalam penggunaan sistem informasi akuntansi, kinerja pegawai sangat berperan penting. Penilaian tentang kinerja pegawai semakin penting ketika perusahaan akan melakukan reposisi pegawai. Dengan adanya sistem informasi akuntansi perusahaan dapat lebih mudah mengetahui kinerja dan posisi yang tepat bagi pegawai.

Organisasi atau perusahaan menanamkan investasi yang besar untuk memperbaiki kinerja pegawai atau organisasi berkaitan dengan implementasi teknologi dalam suatu system informasi (Sumardiyanti, 1999). Goodhue (Jumaili, 2005) mengajukan konsep evaluasi pemakai untuk melihat 
keberhasilan pengimplementasian suatu sistem informasi. Secara umumkonsep evaluasi pemakai adalah suatu penilaian terhadap pemakai sesuatu barang atau jasa terhadap sikap atau kepercayaan mereka menggunakan sesuatu sistem tersebut. Dalam konteks penelitian sistem informasi pemakai akan diberikan evaluasi berdasarkan pada suatu kenyataan apakah sistem informasi yang diterapkan dalam perusahaan sesuaidengan kebutuhan dan kemampuannya.

Kinerja pegawai merupakan fondasi dari kinerja perusahaan. Oleh karena itu, penting untuk memahami beberapa perilaku pegawai dalam perusahaan sebelum menilai kinerja seorang pegawai. Kinerja pegawai seringkali dikaitkan dengan karakteristik jenis pekerjaan, jenis industri, serta kemampuan teknologi dan sistem yang dipakai (Ivancevich, Konopaske, \& Matteson, 2005).

Kinerja pegawai merupakan suatu ukuran yang dapat digunakan untuk menetapkan perbandingan hasil pelaksanaan tugas, tanggung jawab yang diberikan oleh organisasi pada periode tertentu, dan relatif dapat digunakan untuk mengukur prestasi kerja atau kinerja organisasi (Septiningtyas, 2010).

Penilaian kinerja pada dasarnya merupakan penilaian perilaku manusia dalam melakukan peran yang dimainkannya untuk mencapai tujuan organisasi. Sumardiyanti (1999) mengungkapkan bahwa organisasi atau perusahaan menanamkan investasi yang besar untuk memperbaiki kinerja pegawai atau organisasi berkaitan dengan implementasi teknologi dalam suatu sistem informasi.

\section{HIPOTESIS}

\section{Pemanfaatan sistem informasi akuntansi berpengaruh positif dan signifikan terhadap kinerja pegawai PT. KMA Solo}

Pengaruh penggunaan atau pemanfaatan sistem informasi akuntansi terhadap kinerja pegawai juga dijelaskan oleh The D\&M Information System Success Model. Pada teori ini dijelaskan bahwa penggunaan atau pemanfaatan Sistem informasi akuntansi akan menimbulkan kepuasan pengguna yang akan berdampak pada kinerja pegawai dan kinerja organisasi.

Teori yang telah dibahas sebelumnya memperkuat penelitian yang dilakukan oleh Kadek Wahyu Indra lesmana dan I.G.N. Agung Suaryana (2014) dengan hasil Semakin baiknya penggunaan SIA, maka semakin baik pula Kinerja pegawai. Sistem Informasi Akuntansi berpengaruh tehadap peningkatan Kinerja pegawai sebesar $34,5 \%$.

$\mathrm{H}_{1}$ : ada pengaruh positif dan signifikan pemanfaatan sistem informasiakuntansi terhadapkinerja pegawai PT. KMA Solo

\section{Kualitas sistem informasi akuntansi berpengaruh positif dan signifikan terhadap kinerja pegawai PT. KMA Solo}

Kualitas sistem informasi akuntansi memberikan pengaruh teknis terhadap penggunaan sistem informasi akuntansi. Kinerja pegawai yang baik tentunya akan turut memberikan andil dalam peningkatan kinerja organisasi.

Pada penelitian yang dilakukan oleh Purwaningsih (2010), analisis yang dihasilkan adalah kepuasan pengguna secara signifikan dipengaruhi oleh kualitas sistem, kualitas informasi dan kualitas pelayanan. Sebagai tambahan, kinerja pegawai yang disebabkan oleh penggunaan sistem, dipengaruhi signifikan oleh kualitas sistem, kualitas informasi, kualitas pelayanan, task-technology fit, dan kepuasan pengguna.

H2: ada pengaruh positif dan signifikan kualitas sistem informasi akuntansi terhadap kinerja pegawai PT. KMA Solo

\section{Keamanan sistem informasi akuntansi berpengaruh positif dan signifikan terhadap kinerja pegawai PT. KMASolo}

Suatu sistem informasi akuntansi tentunya tidak luput dari resiko kerusakan sistem. Berbagai ancaman yang datang dapat merusak efektivitas sistem bahkan dapat merusak semua data yang ada. Ancaman seperti virus dapat merusak sistem yang ada. Maka dari itu diperlukan system keamanan yang dapat melindungi sistem informasi dalam perusahaan. 
Keamanan atas sistem akan mendorong minat pengguna terhadap pemanfaatan Sistem Informasi Akuntansi karena keamanan data dipercaya dapat memberikan keuntungan bagi pengguna sistem, misalnya dengan terbatasnya akses pegawai atas segalain formasi dalam sistem informasi akuntansi serta data terbebas dari gangguan yang tidak disengaja. Selanjutnya, jaminan akan keamanan data juga dapat mempengaruhi kinerja individu. Hal tersebut sesuai dengan Technology Acceptance Model (TAM) pada dimensi Pesepsi Kegunaan (Perceived Usefulness), yaitu dimana seseorang percaya bahwa penggunaan sistem informasi dapat meningkatkan kinerjanya.

Penelitian yang dilakukan oleh Perdanawati(2014), yang menguji pengaruh usur-unsur kepuasan pengguna, yaitu kelengkapan fungsi atau fitur, stabilitas atau keandalan, kemudahan penggunaan, inovasi, keamanan dan fleksibilitas, terhadap efisiensi dan efektivitas kerja pengguna aplikasi sistem informasi akuntansi.Variabel yang berpengaruh terhadap efisiensi kerja pengguna adalah kelengakapan fungsi dan fleksibilitas, sedangkan pada variabel efektivitas kerja pengguna, hanya variabel keamanan yang berpengaruh secara signifikan.

H3: ada pengaruh positif dan signifikan keamanan sistem informasi akuntansi terhadap kinerja pegawai PT. KMA Solo

\section{Saranapendukung sistem informasi akuntansi berpengaruh positif dan signifikanterhadap kinerja pegawai PT. KMA Solo}

Sarana pendukung sisteminformasi akuntansi dipercaya dapat mempermudah seorang pegawaiuntuk menyelesaikan pekerjaannya. Sarana pendukung dapat berupa lingkungan kerja yang sesuai dan nyaman, optimalisasi penggunaan sistem informasi akuntansi pada aktivitasnya, serta penggunaan teknologi lain yang dapat menambah motivasi pegawai untuk bekerja lebih baik.

Hasil penelitian terdahulu yang dilakukan oleh Warisno (2009) mengatakan bahwa secara simultan kualitas sumber daya manusia, komunikasi, sarana pendukung, dan komitmen organisasi berpengaruh secara signifikan terhadap Kinerja SKPD pada Pemerintahan Provinsi Jambi. Namun secara parsial, sarana pendukung dan komitmen organisasi tidak berpengaruh secara signifikan terhadap kinerja SKPD.

H4: ada pengaruh positif dan signifikan sarana pendukung sistem informasi akuntansi terhadap kinerja pegawai PT. KMA Solo

\section{METODE PENELITIAN}

Objek Penelitian

Penelitian ini dilakukan dengan mengambil objek penelitian di PT. KMA Solo.

\section{Definisi Operasional Variabel}

\section{Pemanfaatan Sistem Informasi Akuntansi(X1)}

Pemanfaatan Sistem Informasi Akuntansi merupakan tingkat integrasi Sistem Informasi Akuntansi pada pelaksanaan tugas-tugas akuntansi. Pemanfaatan Sistem Informasi akuntansi dapat dilakukan pada aktivitas perusahaan yang terbagi ke dalam beberapa subsistem dari Sistem Informasi Akuntansi, yaitu (Hall, 2009): Sistem pemrosesan transaksi (Transaction Processing System-TPS) Sistem buku besar atau pelaporan keuangan (General ledger or Financial Reporting System-GL/FRS), Sistem pelaporan manajemen (Management ReportingSystem-MRS).

Indikator pemanfaat sistem informasi akuntansi dalam penelitian ini adalah pemakaian computer.

\section{Kualitas Sistem InformasiAkuntansi(X2)}

Kualitas Sistem Informasi Akuntansi dapat dibagi ke dalambeberapa dimensi. Hal ini dijabarkan oleh Wardhana (2013), yaitu: Performance (kinerja) Features (fitur) Reliability (kehandalan) Conformance (kesesuaian) Durability (ketahanan), Service ability (kemudahan perbaikan) Aesthetics (estetika/keindahan) Perceived quality

Indikator yang menjadi tolok ukur dari variabel kualitas sistem informasi akuntansi dalam penelitian ini yaitu persepsi kegunaan dan kemudahan penggunaan. 


\section{Keamanan SistemInformasi Akuntansi(X3)}

Keamanan dataatas ancaman pada sistem informasi akuntansi yang diterapkan perusahaan. Ancamanyang mungkin diperoleh menurut Romney dan Steinbart (2011) adalah : Kehancuran karena bencana alam dan politik. Kesalahan pada software dan tidak berfungsinya peralatan.

Tindakan tidak sengaja Tindakansengaja (kejahatan komputer)

\section{Sarana Pendukung Sistem Informasi Akuntansi (X4)}

Adanya sarana pendukung dapat mengoptimalkan penerapan Sistem Informasi Akuntansi. Hal tersebut dapat berupa ketersediaan ruangan yang cukup dan rapi, serta penggunaan perangkat pelengkap lainyang mendukung penerapan Sistem Informasi Akuntansi.

Indikator variabel sarana pendukung sistem informasi akuntansi dalam penelitian ini adalah kemudahan penggunaan, keandalan sistem.

\section{Kinerja Pegawai(Y)}

Menurut Gibson (1987), Kemampuan dan keterampilan merupakan faktor utama yang mempengaruhi perilaku kerja dan kinerja pegawai, sedangkan faktor yang tidak secara langsung mempengaruhi adalah demografis. Hal ini diungkapkan kembali oleh Robbins, yaitu kinerja dapat dinilai diperkirakan dengan menilai pengetahuan, keterampilan, dan kemampuan pegawai.

Keberhasilan kinerja pegawai dapat diukur dengan melihat pengaruh penerapan Sistem Informasi Akuntansi terhadap penyelesaian tugas, yang kemudian menjadikan pengguna lebih kreatif dan produktif, dan pada akhirnya akan membantu pengguna meningkatkan kinerja.

\section{HASILPENELITIAN \\ Uji Normalitas}

Berdasarkan hasil perhitungan uji Kolmogorov Smirnov dapat diketahui bahwa nilai p-value ternyata lebih besar dari $(\mathrm{p}>0,05)$ yaitu 0,769 , maka dapat disimpulkan bahwa pernyataan responden tentang kinerja pegawai memiliki sebaran data yang normal.

\section{Uji Heteroskedastisitas}

Berdasarkan hasil Uji Heteroskedastisitas pada tingkat signifkasi 5\% semua koefisien regresi tersebut tidak signifikan (yaitu dengan tingkat signifikansi $>0,05$ ), sehingga dapat disimpulkan bahwa tidak terjadi heteroskedastisitas dalam persamaan.

\section{Uji Autokorelasi}

Berdasarkan hasil perhitungan diperoleh nilai Durbin Watson sebesar 1,936 pada tabel statistik dengan menggunakan level ofsignifikan $5 \%, \mathrm{~K}=4$ dan $\mathrm{N}=50$ diperoleh $\mathrm{d} \mathrm{L}=1,613$ dan $\mathrm{d} \mathrm{U}=1,736$. Karena nilai1,936 berada di atas batas atas dU dan berada di bawah 4 - dU maka dapat disimpulkan bahwa regresi yang diteliti telah terbebas dari masalah autokorelasi.

\section{Uji Multikolinearitas}

Berdasarkan hasil uji multikolinearitas, nampak bahwa model regresi tersebut tidak terjadi multikolinieritas karena nilai $\mathrm{VIF}<10$ danTolerasi> 0,1 ; serta diperkuat dengan hasil ujikoefisien determinasi yang menunjukkan bahwa nilai $\mathrm{R}^{2}$ adalah 0,542 sehingga tidak melebihi 0,9 .

\section{Analisis Regresi LinierBerganda}

Berdasarkan hasiluji linier berganda, maka diperoleh hasilpersamaan linier sebagai berikut:

$\mathrm{Y}=5,121+0,251 \mathrm{X}_{1}+0,085 \mathrm{X}_{2}+0,105 \mathrm{X}_{3}+0,421 \mathrm{X}_{4}$

Dari persamaantersebut di atas, dapat diperoleh penjelasan sebagai berikut:Apabila $\mathrm{X}_{1}$ terdapat pertambahan 1 butir,maka Y akan bertambah 0,251butir. Atau dapat diartikan jika pada populasi tersebut terdapat perubahanpada pemanfaatan sistem informasi akuntansi sebesar1\%, maka akan terjadi perubahan pada Y sebesar $0,251 \%$.

Apabila $\mathrm{X}_{2}$ terdapat pertambahan 1 butir maka $\mathrm{Y}$ akan bertambah 0,085 butir. Atau dapat diartikan jika pada populasi tersebut terdapat perubahan pada kualitas system informasi akuntansi sebesar $1 \%$, maka akan terjadi perubahan pada $Y$ sebesar 0,085 point.

Apabila $\mathrm{X}_{3}$ terdapat pertambahan 1 butir maka Y akan bertambah 0,105 butir. Atau dapat diartikan jika pada populasi tersebut terdapat perubahan pada keamanan sistem informasi akuntansi sebesar $1 \%$, maka akan terjadi perubahan pada Y sebesar 0,105 point. 


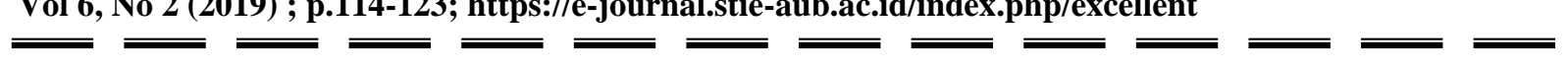

Apabila X4 terdapat pertambahan 1 butir maka Y akan bertambah 0,421 butir. Atau dapat diartikan jika pada populasi tersebut terdapat perubahan pada sarana pendukung sistem informasi akuntansi sebesar $1 \%$, maka akan terjadi perubahan pada Y sebesar0,421 point.

Apabila $\mathrm{X}_{1}, \mathrm{X}_{2}, \mathrm{X}_{3}$ dan $\mathrm{X}_{4}$ tidak ada perubahan, maka $\mathrm{Y}$ akan mengalami perubahan sebesar 5,121 butir. Dengan kata lain jika pada populasi tersebut tidak terdapat perubahan (0 point) yang mendukung, maka akan terjadi penurunanYpada populasi tersebut sebesar 5,121 point.

\section{Uji Hipotesis}

Uji t

Berdasarkan hasiluji t dalam penelitian, terlihat bahwa: Pengaruh pemanfaatan sistem informasi akuntansi terhadap kinerja pegawai.

Hasil uji t pengaruh variabel Pemanfaatan Sistem Informasi Akuntansi terhadap kinerja pegawai PT.KMA Solo diperoleh nilai $t$ hitung 2,642lebih besar dari nilai t tabel 1,699 dengan nilai signifikansi 0,011 yang lebih kecil dari 0,05 maka Ho ditolak, yang berarti bahwa variabel Pemanfaatan Sistem Informasi Akuntansi berpengaruh signifikan terhadap kinerja pegawai PT. KMA Solo.

Pengaruh kualitas sistem informasi akuntansi terhadap kinerja pegawai Hasil uji t pengaruh Kualitas Sistem Informasi Akuntansi terhadap kinerja pegawai PT. KMA Solo diperoleh nilai t hitung 2,644 lebih besar dari nilai t tabel 1,699 dengan nilai signifikansi 0,011 lebih kecil dari 0,05 maka Ho ditolak, yang berarti bahwa variable Kualitas Sistem Informasi Akuntansi berpengaruh signifikan terhadap kinerja pegawai PT. KMASolo.

Pengaruh keamanan sistem informasi akuntansi terhadap kinerja pegawai. Hasil uji t pengaruh Keamanan Sistem Informasi Akuntansi terhadap kinerja pegawai PT. KMA Solo diperoleh nilaithitung 2,342lebih besar dari nilai t table 1,699 dengannilai signifikansi 0,024 lebih kecil dari 0,05 maka Ho ditolak,yang berarti bahwa variabel Keamanan Sistem Informasi Akuntansi berpengaruh signifikan terhadapkinerja pegawai PT. KMA Solo.

Pengaruh sarana sistem informasi akuntansi terhadap kinerja pegawai Hasil uji t pengaruh Sarana Sistem Informasi Akuntansi terhadap kinerja pegawai PT.KMA Solo diperoleh nilai t hitung 3,579 lebih besar dari nilai t tabel 1,699 dengan nilai signifikansi 0,001 lebih kecil dari 0,05 maka Ho ditolak, yang berarti bahwa variabel Sarana Sistem Informasi Akuntansi berpengaruh signifikan terhadap kinerja pegawai PT. KMASolo.

Uji F

Berdasarkan hasil uji $\mathrm{F}$, dapat diketahui hasil perhitungan menunjukkan nilai $\mathrm{F}$ hitung 13,302 lebih besar dan nilai $\mathrm{F}$ tabel 2,76 dengan signifikansi 0,000 lebih kecil dari 0,05 maka Ho ditolak, berarti ada pengaruh yang signifikan pada variabel Pemanfaatan Sistem Informasi Akuntansi, Kualitas Sistem Informasi Akuntansi, Keamanan Sistem Informasi Akuntansi, dan Sarana Pendukung Sistem Informasi Akuntansi terhadap kinerja pegawai PT. KMA Solo secara simultan.

Uji Koefisien Determinasi $\left(\mathbf{R}^{2}\right)$

Berdasarkan hasil perhitungan yang dilakukan dengan analisis statistik terhadap 50 orang responden dengan kuesioner didapat nilai $R$ Square $\left(R^{2}\right) 0,542$ dan nilai Adjusted $R$ Square (Adjusted $R^{2}$ ) 0,501 .

Dari hasil perhitungan tersebut dapat disimpulkan bahwa model yang dipergunakan variabelvariabel bebasnya memberikan sumbangan positif yaitu sebesar $54,2 \%$ terhadap variabel terikat. Sedangkan variabel lain yang memberikan pengaruh terhadap kinerja pegawai namun tidak diikutsertakan sebagai variabel dalam penelitian ini adalah sejumlah 45,8\%.

\section{PEMBAHASAN}

Berdasarkan hasil dari klasifikasi responden diatas dapat diketahui bahwa responden yang merupakan pegawai PT. KMA Solo memiliki tingkat pendidikan bermacam mulai dari SMU/A/K, D3 dan S1. Responden yang memiliki tingkat pendidikan SMU/A/K sebesar $40 \%$, yang memiliki tingkat pendidikan D3 sebesar40\% dan yang memiliki tingkat pendidikan S1adalah sebesar 20\%. Berdasarkan teori yang digunakan dalampenelitian ini bahwa variabel yang mempengaruhi kinerja pegawai yaitu Pemanfaatan Sistem Informasi Akuntansi, Kualitas SistemInformasi Akuntansi, Keamanan Sistem 
Informasi Akuntansi dan Sarana Pendukung Sistem Informasi Akuntansi. Untuk penjelasan lebih rinci dan jelas adalah sebagai berikut:

Pemanfaatan sistem informasi akuntansi memiliki pengaruh yang positif dan signifikan terhadap kinerja pegawai PT. KMA Solo. Berdasarkan hasil analisis regresi berganda menunjukkan bahwa variabel pemanfaatan sistem informasi akuntansi berpengaruh positif dan signifikan terhadap kinerja pegawai PT. KMA Solo yang ditunjukkan dengan hasil nilaiujit sebesar 2,642 yang berarti bahwa nilai uji t lebih besar daripada nilai t tabel.

Variabel berikutnya adalah kualitas system informasi akuntansi yang dalamhasil penelitian ini menunjukkan bahwa kualitas sistem informasi akuntansimemberikan pengaruh yang positif dan signifikan terhadap kinerja pegawai PT. KMA Solo. Hasil ini ditunjukkan dengan nilai uji t lebih besar daripada nilai $t$ tabel yaitu sebesar 2,644 pada nilai uji t variabel kualitas sistem informasi akuntansi.

Keamanan sistem informasi akuntansi merupakan salah satu faktor yang berpengaruh terhadapkinerja pegawai. Berdasarkan hasil penelitian ini, menunjukkan bahwa keamanan sistem informasi akuntansi berpengaruh positif dan signifikan terhadap kinerja pegawai PT. KMA Solo dengan dibuktikan hasil uji t hitung sebesar2,342 lebih besar daripada nilai t tabel.

Sarana pendukung sistem informasi akuntansi salah satu variabel bebas atau variabel yang memiliki pengaruh dalam penelitian ini yang variabel terikatnya adalah kinerja pegawai. Berdasarkan hasildata yang telah diolah, menunjukkan bahwa sarana pendukung sistem informasi akuntansi memberikan pengaruh positif dan signifikan terhadap kinerja pegawai PT. KMA Solo. Hal ini dibuktikan dengan nilai uji t yang dimiliki oleh variabel sarana pendukung sistem informasi akuntansi lebih besar daripada nilai $\mathrm{t}$ tabel dengan nilai $\mathrm{t}$ hitung sebesar 3,579 pada variabel sarana pendukung sistem informasi akuntansi.

Berdasarkan hasil analisis penelitianyang dengan melihat hasil perhitungan nilai uji $\mathrm{F}$, dapat diketahui bahwa keempat variabel bebas dalam penelitian ini yaitu pemanfaatan sistem informasi akuntansi (X1), kualitas sistem informasi akuntansi (X2), keamanan sistem informasi akuntansi (X3) dan sarana pendukung sistem informasi akuntansi (X4) secara bersama-sama berpengaruh positif dan signifikan terhadap kinerja pegawai PT.KMA Solo. Hal ini dibuktikan dengan nilai hasil uji F sebesar 13,302 .

Melihat dari keseluruhan hasil perhitungan data penelitian, dapat diketahui bahwa variabel yang paling besar atau dominan berpengaruh terhadap variabel terikat yaitu kinerja pegawai $(\mathrm{Y})$ dalam penelitian ini adalah variabel sarana pendukung sistem informasi akuntansi yang memiliki nilai uji $t$ hitung paling besar dari pada nilai uji t hitung variabel yang lainnya yaitu sebesar 3,579.

$\mathrm{H}_{1}$ : ada pengaruh positif dan signifikan pemanfaatan sistem informasi akuntansi terhadap kinerja pegawai PT. KMA Solo.Hipotesisini terbukti kebenarannya dengan bukti bahwa hasil nilai dari uji t dapat diketahui bahwa $t$ hitung variabel pemanfaatan sistem informasi akuntansi diterima pada taraf $5 \%$.

$\mathrm{H}_{2}$ : ada pengaruh positif dan signifikan kualitas sistem informasi akuntansi terhadap kinerja pegawai PT. KMA Solo. Hipotesis ini terbukti kebenarannya dengan bukti bahwa hasil nilai dari uji t dapat diketahui bahwa t hitung variabel kualitas sistem informasi akuntansi diterima pada taraf 5\%.

$\mathrm{H}_{3}$ : ada pengaruh positif dan signifikan keamananan sistem informasi akuntansi terhadap kinerja pegawai PT. KMA Solo.Hipotesis ini terbukti kebenarannya dengan bukti bahwa hasil nilai dari uji t dapat diketahui bahwa t hitung variabel keamanan sistem informasi akuntansi diterima pada taraf $5 \%$.

$\mathrm{H}_{4}$ : ada pengaruh positif dan signifikan sarana pendukung sistem informasi akuntansi terhadap kinerja pegawai PT.KMA Solo. Hipotesis ini terbukti kebenarannya dengan bukti bahwa hasil nilai dari uji t dapat diketahui bahwa t hitung variabel sarana pendukung sistem informasi akuntansi diterima pada taraf $5 \%$.

\section{KESIMPULAN}

Berdasarkan hasil analisis data penelitian yang telah diuraikan dalam bab sebelumnya, maka dapat diambil kesimpulan sebagai berikut : Berdasarkan hasil analisis uji menunjukkan bahwa pemanfaatan sistem informasi akuntansi berpengaruh positif terhadap kinerja pegawai PT. KMA Solo dengan dibuktikan nilai ujt hitung sebesar 2,642. Berdasarkan hasil analisis uji menunjukkan bahwa 
kualitas sistem informasi akuntansi berpengaruh positif terhadap kinerja pegawai PT.KMASolo dengan dibuktikan nilai uj thitung sebesar 2,644.

Berdasarkan hasil analisis uji menunjukkan bahwa keamanan sistem informasi akuntansi berpengaruh positif terhadap kinerja pegawai PT. KMA Solo dengan dibuktikan nilai uj $t$ hitung sebesar 2,342.

Berdasarkan hasil analisis uji menunjukkan bahwa sarana pendukung sistem informasi akuntansi berpengaruh positif terhadap kinerja pegawai PT. KMA Solo dengan dibuktikan nilai ujt hitung sebesar 3,579 .

\section{KETERBATASAN} sebagai berikut :

Penelitian yang peneliti lakukan ini masih memiliki keterbatasan dalam penelitian, antara lain

Penelitian ini hanya terdapat beberapa variabel bebas yang berpengaruh terhadap variabel kinerja pegawai yaitu hanya terdapat empat variabel bebas antara lain pemanfaatan sistem informasi akuntansi (X1), kualitas sistem informasi akuntansi (X2), keamanan sistem informasi akuntansi (X3) dan sarana pendukung sistem informasi akuntansi (X4). Diharapkan penelitian yang akan datang dapat menambah variabel.

Penelitian ini terbatas dalam tempat penelitian dan pengambilan sampel yaitu sampel yang diambil adalah pegawai PT. KMA Solo, sehingga hasil penelitian ini tidak dapat digunakan untuk menggeneralisir kinerja pegawai-pegawai di tempat yang lain.

\section{SARAN}

Kepada Pimpinan PT. KMA Solo agar informasi-informasi terkait kepemimpinan, perencanaan strategis, fokus pada pelanggan, pengukuran, analisis, dan pengelolaan pengetahuan, fokus pada tenaga kerja, operasi dan hasil diteruskan sampai keapda pegawai dengan tingkat paling bawah. Dengan ini, diharapkan pegawai memahami kondisi sebenarnya dari perusahaan, pegawai mengetahui dan mampu menilai seberapa besar keterlibatan mereka serta bagaimana keterlibatan mereka dihargai oleh perusahaan. Selain itu juga, pegawai bias melihat kepedulian perusahaan terhadap pegawai.

Berdasarkan hasil penelitian, diketahui bahwasarana pendukung sistem informasi akuntansi memiliki pengaruh yang lebih besar terhadap kinerja pegawai PT. KMA Solo, diharapkan perusahaan tetap menjaga dan meningkatkan hal tersebut. Dan untuk peningkatan kinerja pegawai yang berhubungan dengan sistem informasi akuntansi, diharapkan perusahaan dapat lebih meningkatkan dan memperbaiki sistem yang masihdianggap terdapat kekurangan.

\section{DAFTARPUSTAKA}

Achmad, Ruky.2001.Sistem Manajemen Kinerja. Jakarta: PT. Gramedia Pustaka

Andhika, Wisnu.2007. Pengaruh Persepsi Karyawan tentang Implementasi Sistem Informasi Berbasis Komputer terhadap Kinerja. Skripsi. Universitas Brawijaya. Malang.

Baridwan. 2004.Intermediate Accounting, Edisi Kedelapan. Yogyakarta: BPFE.

BodnardanHopwood. 2003.Sistem InformasiAkuntansi, Edisi Keenam. Jakarta:Salemba Empat.

Hall,James.2009.SistemInformasiAkuntansi.Jakarta: Salemba Empat

Ivancevich, John M, KonopaskeRobert\&MattesonMichaelT.2005,Perilaku Dan Manajemen Organisasi(Alih Bahasa Gina Gania),Edisi Tujuh, Erlangga, Jakarta.

Jones, F.L. and Rama, D. 2006. Accounting Information System 1st Edition. South Western: Thomson.

Jumaili, Salman. 2005.Kepercayaan Terhadap TeknologiSistem Informasi BaruDalam Evaluasi Kinerja Individual. Kumpulan Materi Simposium NasionalAkutansiVIII.Solo15-16 September.

Kosasih, Ruchyat. 1995.Sistem InformasiAkuntansi dan Organisasi Perusahaan. Edisi ketiga, Penerbit Erlangga, Jakarta

Mangkunegara, A.P. 2002. Manajemen Sumber Daya Perusahaan. Bandung: ROSDA.

Marshall B.Romney,Paul john steinbart. 2006.Sistem Informasi Akuntansi. Jakarta: SalembaEmpat.

Romney, M.B, and Steinbart, J.P.2011. Accounting Information Systems, $11^{\text {th }}$ Edition.New Jersey:Prentice Hall,Inc. 
Septiningtyas, Dwina. 2010.Pengaruh Efektivitas Penggunaan dan Kepercayaan atas TeknologiSistem Informasi Akuntansi Terhadap KinerjaAuditor Internal. Jurnal Akuntansi dan Bisnis. Depok:Universitas Gunadarma.

Sumardiyanti, S.V. 1999.Pengaruh Pemanfaatan Atas Kecocokan Tugas TeknologiSistem Informasi Terhadap Pencapaian KinerjaIndividual. Tesis Program Pascasarjana,UGM Yogyakarta.

Titisari, Purnamie. 2015. Peranan Organizational Citizenship Behavior (OCB) Dalam Meningkatkan Kinerja Karyawan. Jakarta:Mitra WacanaMedia.Utama. 